811.163.41'36"1894"

811.163.41'367

https://doi.org/10.18485/sj.2020.25.1.17

ЈЕЛЕНА Р. ЈОВАНОВИЋ СИМИЪ

Универзитет у Београду

Филолошки факултет
Оригинални научни рад

Примљен: 15. 10. 2019.

Прихваћен: 15. 01. 2020.

\title{
НАПОМЕНЕ О СИНТАКСИ У НОВАКОВИЋЕВОЈ СРПСКОЈ ГРАМАТИЦИ*
}

Аутор је себи поставио задатак да у овоме раду опише и процени Новаковићев допринос српској граматичкој литератури, и науци о језику уопште, са посебним освртом на Српску граматику (1894). Пажња ће бити посвећена научним погледима, начину излагања, као и терминолошким решењима Новаковићевим, како она стоје у односу на данашња схватања о тим питањима, и у данашњој граматичкој пракси.

Кључне речи: граматика, синтакса, реченица, падеж, време.

\section{1. УВОД}

1. Доста се писало о Стојану Новаковићуํㅜ ${ }^{1}$ као и о његовм филолошком раду $^{2}$, а наша је намера у овом раду да се осврнемо на неке Новаковићеве појмове и термине са гледишта данашњег писца граматике (Симић/Јовановић 2007), и да покушамо те разлике објаснити као напредак граматичке мисли код нас. Колика је, хоћемо рећи, дистанца коју је превалила лингвистичка наука за

*jelenajo@beograd.com

** Овај рад написан је у оквиру пројекта 178014 Динамика структура савременог српског језика, који финансира Министарство просвете, науке и технолошког рзавоја Републике Србије.

${ }^{1}$ Исп. биоблиографске податке у: ЕСН 2008.

${ }^{2}$ Исп.: Белић 1999, Симић 1991. - В. и рад Р. Симића у овом часопису. 
последњих сто двадест година. А остављамо по страни школску литературу последњих десетак година, која иде својим, не увек исправним путевима.

2. А. Белић налази да Новаковић - који се филолошким радом бавио углавном повремено и узгред, претрпан другим пословима и дужностима од националног интереса и државних потреба - није увек био на висини свог задатка. Али да је ипак био најбољи граматичар свога доба, да је унапредио и терминологију и граматичку мисао српску у целини (Белић 1999: 456).

Новаковић се старао, у главноме, да популарише у гимназији онај граматички материал који је находио у научним делима свога времена; где није било научних пространих расправа, ту је Новаковић ишао самостално, дајући у нацрту смисао појединих граматичких одељака. Ја мислим да су те партије Новаковићеве боље него оне где се држао научне литературе; најслабији му је II-ги део граматике (основе), затим долазе облици, па тек онда синтакса и гласови. У колико је где било мање материала, укарареног у формалне категорије, у толико је тај део граматике прегледнији и јаснији код Новаковића, зато је Наука о гласовима боља од Синтаксе, а Синтакса од осталих.

Зависност од Даничићевих и Миклошићевих радова, у којима распоред грађе и објашњења нису у складу са захтевима граматике (а и сама истраживања имају у извесном смислу 'механички' смисао), учинила је те одељке - хоће рећи Белић - неинвентивним и нејасно изложеним. Где је био самосталан, имао је већег успеха и као граматичар, али и као филолог, истраживач језика.

3. Граматика је компонована на необичан начин за данашње појмове. Претходи јој више од двадесет страница 'Приступа', за којима следе четири одељка, и на крају 'Додатак' о правопису. Одељци су: 'Наука о гласовима', 'Наука о основама', заправо о творби речи, 'Наука о облицима', 'Наука о реченици'. Нас ће занимати приступни део и наука о реченици, дакле синтакса. Очекивали бисмо да приступне лекције буду посвећене језику који представља садржај дела, дакле о настанку и развоју Вуковога књижевног језика итд. Међутим, о тим питањима Новаковић није у свом делу заузео експлицитни став. Приступ је такође и конципиран необично, вероватно као скуп инструкција за приступ језичком знаковљу.

4. Приступ, па с тим и Граматика (после општих напомена о природи језика), започиње дефиницијом реченице. То је, свакако, једна од могућности приступа анализи језичке грађе, и ми то питање остављамо по страни.

4.1. У теорији реченице Новаковић употребљава термине 'реченица' ('главна' и 'споредна'), 'подмет', 'прирок', 'додатак'. Данашње називље захватила је у већој мери интернационализација, па уместо 'подмета' имамо 'субјекат', а уместо 'прирока' 'предикат'. Општи назив 'додатак' више се не употребљава, него се узимају посебни термини за врсте 'додатака': 'атрибут', 'адеврбијал' ('прилошка одредба'), 'објекат' и др. У схватању реченице, међутим, Новаковић се колеба између аристотеловске и касније граматичарске теорије. Погледаћемо почетне дефиниције: 
Једна мисао, исказана речима, зове се реченица. Обично се мисли једна с другом везују и друже, па то бива и с реченицама, које нису ништа друго до изговорене мисли. Језик у употреби није ништа друго него гомила речи у реченице сложена.

а) На једној страни се реченицом сматра 'мисао'; то што је она 'исказана речима' није најбитније, нити је битно како су речи сложене у реченице, јер од тога као да ништа не зависи, ни при уобличењу појединачне мисли, нити пак у слагању мисли у више целине. Мисао је све, а реч само њена сенка.

б) На другој пак страни Новаковић изванредно запажа да постоји 'језик у употреби', и да њега чине речи 'у реченице сложене'. Пропустио је само да промисли о речима у реченици: да ли оне чине само безобличну 'гомилу', или су некако сређене и уређене.

4.2. На следећој страници књиге (стр. 2) аутор понавља дефиницију реченице, сада са додатком дефиниције њених основних делова:

Чим се бар две представе међу собом вежу, било тврђењем било одрицањем, одмах постаје мисао; а мисао, чим се изговори или напише, постаје реченица. у свакој реченици (изговореној мисли) има двоје:

1. Оно о чему се говори, и то се зове подмет, и

2. Оно што се о томе подмету каже, и то се зове прирок.

Тако нпр. у реченици Ученик пише говори се о ученику да пише, те је зато у њој подмет ученик, а прирок пише.

Поново се не води довољно рачуна о разлици између језичке и значењске стране језика, па се подмет дефинише као оно о чему се говори, а не каже се да је то реч која означава то 'о чему се говори', као што и прирок јесте реч која означава то што се подмету приписује. Но, иако недовољно јасно, читалац ипак постаје свестан слојевитости језичког знака - речи и мисли. Томе доприноси и тврдња ауторова о 'речи и представи': „Свака реч казује неку представу, тј. значи нешто што умом мислимо или чулима (видом, пипањем, слухом итд) опажамо у свету око нас или у нама самим" (стр. 1).

4.3. Новаковић не познаје термин 'проширене реченице', али говори о 'додатцима или допунама', који 'описују, допуњују или пространије казују оно што значи подмет и прирок'. Реченица дакле има 'додатке' уз подмет или прирок (биполарне чланове Новаковић не помиње, нити другостепене 'додатке уз додатке'). ${ }^{3}$ Истовремено се скреће пажња на 'положај подмета, прирока и додатака', тј. на оно што се данас подразумева под 'редом речи у реченици' (линеарном структуром њеном). 'Положај' није одређен чврстим структурним правилима, већ зависи од хијерархије мисли и интонацијске структуре у вези с тим. При томе упућује једино на антиципацијску 'фронтализацију', тј. на изношење оне речи чији се садржај жели посебно истаћи на почетак (стр. 4):

${ }^{3}$ То се може сматрати малом недоследношћу, јер касније утврђује да 'споредне' реченице могу стајати, сем уз подмет и прирок, и уз њихове додатке (в. даље). 
Ни подмет, ни прирок, ни додатке њихове не треба тражити по месту, него по значењу, јербо се често ред речи подешава по ономе што хоће да се у исказивању мисли живље истакне, или на што хоће да се већа пажња привуче.

Тако нпр. место Рђа не приања за злато, где би био подмет на првом, прирок на другом, а додатци прирокови после њега на трећем месту, лепше се каже: $3 a$ злато рђа не приањ $а$, јербо се на додатак прироков жели привући већа пажња. - Место Бог помаже Радиши, тога ради се каже: Радиши Бог помаже...

Из датих формулација ипак је јасно да аутор у позадини подразумева да постоји некакав основни ред речи који он не дефинише, али подразумева као полазишни тип који варијацијом даје конкретне форме: 'подмет на првом, прирок на другом, а додатци прирокови после њега'

4.4. Појам сложене реченице аутор обрађује у два корака.

а) У првом кораку не дефинише појам, већ само упозорава на постојање 'реченица главних и споредних' (стр. 4-5):

Подмету и прироку и њиховим додатцима додају се често за попуну и ширење реченице, место обичних речи, и целе реченице. Реченице, којима то додавање бива, тиме постају главне, а оне које се појединим деловима главне реченице додају зову се споредне или додане реченице.

[...] У реченици Зна шта ияар вечера, главна је реченица зна, и у њој само прирок, јер се подмет он разуме по самом глаголском облику, а додана је ита ичар вечера [...].

Изгледа да Новаковић не прави разлику међу 'додацима', а био је на корак од тога да 'додацима' сматра одредбе, а да од њих разграничи 'допуне'. Но овако схватање какво Новаковић износи о овим јединицама за данашње појмове је прилично сумарно и синкретично.

4.5. Као што је код 'додатака' устврдио да њихов распоред не зависи од неких формалних правила, тако је учинио и са 'споредним' реченицама; али сад не прати линеарну структуру већ 'смисао' (5-6):

Које је главна, а које споредна реченица, разликује се не по месту, него по потпуном или непотпуном смислу и значењу реченице. Главна реченица има потпуног смисла и кад се од ње све споредне поиздвајају; споредне пак, кад се одвоје од своје главне, обично задржавају неку празнину или непотпуност у значењу [...]:

Од мача ће погинути они који мачем секу.

б) У другом кораку он говори о 'сложеним реченицама или низовима од реченица', и да разликује напоредне од зависних (стр. 6):

Реченице у језику ретко стоје саме за се, него се већином везују једна с другом; зато их налазимо склопљене, на различите начине, у низове веће или мање. Али се у томе склапању или низању реченица увек разликују два начина.

(1) По једноме од тих начина реченице у низу остају самосталне једна од друге, и свака је главна $[\ldots]$ :

Дете дочека и пође с њим. - Скуп више плаћа, а лењ дале иде [...]. 
(2) По другоме начину реченице се нижу тако, да од једне остале зависе, да једне попуњују и објашњују друге, и да се око једне главне друге споредне или додате нижу на разне начине $[\ldots]$ :

Идем у свет, да учим какав занат. - Где се гусле у кући не чују, ту је мртва и кућа и људи. - он м запита од куда сам [...].

5. Сем основних синтаксичких појмова, у приступу се говори о једнини и множини (уопште: „Лица и ствари, које се обично подметом или иначе казују, могу бити у једнини и у множини [...]”, стр. 2), а затим о речима променљивим и непроменљивим, и о свим врстама речи укратко).

\section{2. 'НАУКА О РЕЧЕНИЦАМА'}

1. Под овим насловом обрађује се заправо целокупна синтаксичка проблематика, пре свега много развијеније него у приступу учења о реченици, а затим и употреба падежа и глаголских облика: „У науци о реченицама (синтакси) разматра се како се речи и облици њихови употребљују за састављање реченица" (стр. 248). Склоп реченице, према томе, представља општи предмет синтаксе, а свакако и осталих граматичких дисциплина.

2. Аутор понавља обавештења о 'додатцима' и 'разгранавању реченице'.

a) Уз подмет ${ }^{4}$,додатци могу бити поглавито придевни или самостални додатци (атрибути и апозиције)”. Сада проширује своје налазе и говори о другостепеним 'додатцима': „Додатци не морају припадати подмету или прироку непосредно, него се могу додати и један другом” (254-255). Познаје и атрибутив, али не назива га посебним термином, него га ставља једноставно у ред 'придевних додатака': „Именице могу бити [...] придевни додатак кад су употребљене у смислу придева" (Полегла је бјелица пшеница). Апозицију дефинише као именицу: којом се оно што значи именица уз коју стоји ,управо казује још једанпут, другим неким именом, које му припада када се гледа с некога другог гледишта” (,У ствари је тај самостални додатак од именице скраћена [...] реченица, која се лако може развити у пуну реченицу": Стоји ага, горско звере. - А другима, клетник, мировати не да).

Последњи пример и њему слични упозоравају да апозиција није обавезно пратилац неке именице, што Новаковић није приметио, нити многи лингвисти који долазе после њега. Очито је реч не о именичкој одредби, како хоће Стевановић и други, него еманципована именица са квалификацијском функцијом (Симић/Јовановић 2007: 216-217)

${ }^{4}$ И после Новаковића у граматикама се дуго понављао овакав став, и тек га је, чини се, $\mathrm{M}$. Стевановић (1991) исправио спознавши истину да апозиција и атрибут прате именицу у свим њеним функцијама, не само субјекатској. 
б) Уз прирок 5 долазе 'предмет' - „додатак прироков који стоји поред прелазних глагола у четвртом или другом падежу" (257) (Онда иште суву дреновину. - Ви Грујице ни видели нисте) ${ }^{6}$, и ознаке простора и правца (Онда се он дигне у свет да тражи заната; А месеца јоште нема туна), начина (Бејаше јако захладнело), поређења (Па кроз гору ступа кано муға лака), узрока (Од страха ћеш пасти са коњица), које Новаковић не назива посебним термином.

3. Реченице Новаковић дели на просте и сложене, а са њима и синтаксу на синтаксу просте и синтаксу сложене реченице (260).

a) Поглавље о синтакси просте реченице започиње одужим текстом о 'слагању главних делова реченичних'. Затим долази 'употреба врста речи', где аутор говори о употреби singularia tantum, поређењу, присвојним заменицама (мој и свој итд.), глаголима ${ }^{7}$ - о прелазности, о повратним, префиксалним гл. итд., - глаголском виду и др. У питању вида ('трајања') заступа 'пунктуалну теорију' (276):

Што се тиче трајања радње глаголске, оно се може показати: или непрекидно (продужено), или на разне начине ограничено. Непрекидно је, кад радња траје неко дуже време без ограничавања, као на прилику: летети, горети, вртети, кметовати, ирнети, итд. Ограничено је кад се радњи, која се именује глаголом бележи у трајању њеном: или један тренутак, у ком се она догодила и свршила, нпр. лупнути, дати, стати, скочити, крочити, итд., или крај трајања кроз неко извесно време, нпр.: поирнети, на̀тпевати, увести, провртети, итд., или почетак трајања, за који се не казује докле ће се продужити, нпр.: полетети, забелети се, задрмати, заболети, запевати, итд. - На послетку може се глаголским обликом показати да се радња, било непрекиднога, било ограниченога трајања, у више пута понавља, нпр. ле́тати (више пута летети), сёдати (више пута сести).

Терминолошки аутор затим издваја три класе глагола: несвршене, свршене и 'учестане'.

б) Затим Новаковић даје преглед употребе 'именских облика'. Нпр. 'први падеж' се употребљава као подмет и 'именски прирок' (Ви сте видело свету), 'други' „има најразличнија значења”: својину (кућа мога оца), 'каквоћа' (Дође момче ирна ока), време (Оне године удари град, те побије све село) итд. 'Трећи падеж’ означава „кога се тиче оно што се у осталој реченици каже”, нпр. као циљ (Доће јунак Босни каменитој), 'присвајање' (Златна су јој крила) и др. 'Четврти падеж' „показује ствар на коју прелази, управо на којој се врши радња прелазних глагола” (Градити кућу), у тај падеж „меће се реч којом се хоће да означи мера" (Тежи је једну оку). И тако даље. А. Белић је утврдио да

${ }^{5}$ И ова заблуда пратила је школске граматичаре све до најновијег времена, када је исправљена, те су објекат и прилошка одредба дефинисани као пратећи елеменат глагола у свим његовим функцијама.

${ }^{6}$ „Много су налик на подмет и остали падежи (други, трећи, шести), који се глаголу додају да би се показала веза радње његове са лицима и стварима на којима се врши" (258) (Коме ћеш се приволети царству? - Три пут си ме ропства опростио. - Бацићу се злаћаном јабком).

${ }^{7}$ Исп. о томе у: Симић и Јовановић Симић (2017: 583-593). 
су Новаковићеве интерпретације о падежима урађене на основу Даничићевих истраживања.

в) Оно што је Новаковић рекао у употреби глаголских облика Белић мисли да је резултат оригиналних његових истраживања, и да представља, поред фонетике, најбољи део Граматике. Разгледаћемо укратко то поглавље.

(1) „Садашње време показује радњу која се збива онда када се о њој говори, или се иначе у свако доба догађа" (301). Према нашим најновијим истраживањима ${ }^{8}$ излази да је дефинисање презента без помена општег значења - заправо промашено, јер - ако се основним зачењем било које јединице или облика сматра оно које није 'ометено' контекстом, - онда је презент са општим значењем управо тај основни тип (исп.: Јовановић Симић 2017б: 93-112). Када значи радњу када која се врши 'када се о њој говори', презент је у ствари у својој употреби ограничен тим околностима, а није самостална категорија.

(2) 'Прошаста времена'9 обрађена су збирно, па се за перфекат каже да се њиме означава „радња просто као прошла у онај мах кад се о њој говори” (303). 'Давно прошло време' показује радњу која је „као прошла не у онај мах кад се о њој говори, него далеко пре тога у прошлости (бејах говорио или био сам говорио)”. „Кад се хоће да покаже радња која се догодила у прошлости у ограниченом простору времена, био тај простор целина, почетак или крај, онда се употребљује пређашње свршено (аорист)" (304) (Како стиже, суние грану). 'Пређашње несвршено (имперфекат)' значи радњу „која се догодила у прошлости као трајна или несвршена”.

(3) У питању футура Новаковић се изгледа сувише повео за руским граматикама. Прецењује употребу презента у футурском значењу, а не разликује футур од футура другог ${ }^{10}:$ „Време будуће нема особитога облика у српскоме језику. Оно се по некад казује садашњим временом свршених глагола (које се тога ради каткад слаже с предлогом уз), а обично реченицама сложеним помоћу времена садашњег глагола хтети и бити (хоћу или ћу и будем)" (307).

4. Код сложених реченица Новаковић најпре разликује два поступка склапања њиховог: приређивање и подређивање (326-327):

Приређивањем (coordinatio) су реченице сложене, кад се тако једна с другом у сложену реченицу саставе, да све просте реченице стоје једна према другој као засебни и потпуни делови [...].

Подређивањем (subordinatio) су пак сложене реченице онда, кад је мисао, казана у једној, проста допуна или додатак мисли или речи друге реченице.

${ }^{8} \mathrm{O}$ значењу и употреби глаголских облика, и презента посебно - исп.: Јовановић Симић 2017а (125-137), Јовановић Симић 2018а (219-235), Јовановић Симић 2018б (51-67).

${ }^{9}$ Исп. Јовановић Симић 2017в (25-34), Јовановић Симић 2018в (27-42).

${ }^{10}$ Исп. о томе у: Јовановић Симић 2019 (295-313). 
a1) „Спојним начином су приређене реченице, које обичним начином просто једна за друго следују, и то или без икаквих свеза, или скопчане свезама $u, a, n a$ (пак), те (тер), или упитном речцом ли" (330) (Ко би мене воде напојио, ко ли би ми хладак учинио, тај би души мјесто учинио).

а2) Раздвојним су начином приређене реченице, у којима се набраја више једнаких међу собом чланова, али се не показује да они чине целину, него да сваки члан по вољи може опстати искључујући остале. Оваке се реченице скопчавају свезама или - или ( $a-a, j a-j a$, али - али, јали - јали), ни - ни, нити - нити (воља - воља, које-које)" (331). Аутор је сакупио све поновљене везничке речи у једну класу, али они не чине јединство.

а3) „Кад ли се у једној реченици казује мисао, противна мисли друге реченице, онда су тако приређене реченице супротне, и обично се скопчавају свезама $a(j a)$, али, ну, него (но), већ, ама" (331-332).

б) Пошто подређена реченица „није ништа друго него додатак подметов или прироков, раширен у читаву реченицу" - то је и класификација подређена томе уз који део реченице стоје - дакле на оне које стоје уз подмет и оне уз прирок. Уз подмет стоје, према томе, реченице придевске („којима се у неку руку замењује придевни додатак (атрибут) уз именице”), и именичке („које стоје на место самосталних додатака обе врсте"). Уз прирок иду реченице предметне, реченице којима се казује намера, реченице којима се исказује погодба, реченице у којима се исказје допуштање (пермисивне), реченице за поређење, за место, за време, те за последицу или узрок.

в) Подела зависних реченица мање или више подсећа на ону која се данас може наћи и у граматикама и у научним трактатима; напоредне реченице својим класификацијским особеностима више заостају за зависнима, пре свега овлашношћу увида у њихову природу, а затим и по везницима који им се приписују (ових има и застарелих и провинцијалних у односу на савремено стање норме).

5. Посебно поглавље у Новаковићевој синтакси посвећено је 'скраћивању простих и сложених реченица'.

5.1. Први део тога поглавља садржи излагање о 'непотпуним реченицама', како их називају данашњи граматичари, „у којима нису изречени главни делови" - а Новаковић полази од претпостављеног поступка 'скраћивања изостављањем'.

a) На прво место аутор ставља случајеве 'изостављања споне' (Кућа моја чарна гора, а постеља камен ови) (347).

б) „Када се у сложеним реченицама деси више једнаких подмета или једнаких прирока, онда се те реченице стежу у скраћену сложену реченицу" (И суние је охладнело, једва сипа зрак. - Ми идемо преко села, а облачи преко неба) (248). 
в) Изостављају се и разни 'додатци' када су једнаки у низу реченица (Cad кажи, шта сам ја без круне, шта ли је мој син?).

5.2. Више појава Новаковић обједињује у поглављу о 'скраћивању замењивањем' (349-351).

а) „Целе додане, подређене, реченице могу се стегнути у једну или неколико речи. То се у подређеним реченицама које су додатак подмету, прироку и предмету [...] чини подметовим и прироковим додатком (нарочито самосталним додатцима [...])" (Ми, сиромаси, носимо им колаче. - Нек погинем, јунак на јунаштву).

б) Глаголске прилоге Новаковић сматра скраћеним реченицама (Путујући тако удари на једну воду).

в) Редуктивним процесом замене објашњава се и употреба инфинитива уместо 'подређених реченица за намеру' (Рано рани Туркиња ђевојка, на Марииу платно бијелити. - Кад погледаш с града изнад себе, ништа немаш лијепо виђети).

г) На крају (351) Новаковић упозорава 'књижевнике' на непотребност и ружноћу избегавања инфинитива, што је за данашње време врло актуелно ${ }^{11}$ :

Многи наши писци очигледно беже од начина неодређеног, растварајући га где год доспеју. Ако проуче ово мало примера и потраже их још у врсним делима нашега језика, која се не могу потворити нечистином, увериће се ласно, да тиме крате језику нашем једно од старинских својстава и лепота његових.

\section{3. ЗАКљУЧНА РАЗМАТРАњА}

Завршно поглавље Граматике чине напомене о правопису и интерпункцији, али како је та значајна материја, и заслуга Новаковићева за њено уобличење, и предмет већег броја радова, остављамо је по страни, него ћемо укратко закључити свој преглед синтаксичке проблематике и начина на који се она код Новаковића третира.

1. Одмах ваља напоменути да је у неким детаљима Новаковићева за данашње схватање застарела, и њени налази неупотребљиви.

2. Други су, међутим, мање или више и данас актуелни, и не би их се стидела ни данашња граматичарска литература. Чак би их требало свакако актуелизирати уз прилагодбу нашој данашњој терминологији.

3. Кад је реч о терминологији, данас се заборавило на творца српске граматичке терминологије Ђ. Даничића, и његове напоре у том правцу. Место

\footnotetext{
${ }^{11}$ Исп. о употреби футуроида уместо футура у: Симић 2009 (51-55).
} 
чувања домаћих термина где год је сврсисходно и могуће, ми смо пристали на интернационално граматичко називље, и сасвим заборавили нпр. подмет и прирок, те садашње и прошло време, пређашња времена, будуће, предбудуће, заповедни начин итд., и навикли се на стране називе, како у трактатима 'високе' науке, тако исто и уџбеницима за више, па и за почетне разреде.

4. Последње упозорење Новаковићево тиче се заправо неконтролисаног напредовања балканизма, и постепено напуштање традиционалних особина словенског порекла - не само у питању инфинитива, већ и у неким другим детаљима. Све то чини наш језик мање синтетичним и мање естетичним.

5. На крају ћемо поменути једну особеност Новаковићева стила. Та се особеност мање примећује у његовим граматичким списима, а више у осталим. На њу је скренуо пажњу А. Белић (1999: 462) као на Новаковићев допринос стилистичком развоју српскога књижевног језика, који се може ишчитати из његових списа. „Новаковић је део живота нашег књижевног језика новије епохе, у којој су учествовали у сличном правцу и други његови савременици, само је Новаковић са више свесности и често већом снагом корачао унапред. Ако се може рећи да је према данашњем схватању нашем, језик Вуков и Даничићев носио сувише описни, епски карактер, Новаковић му је у делима својим дао више пословни тип, и ако се не може рећи да се одвојио потпуно од својих непосредних претходника."

\section{ИЗВОРИ}

Новаковић 1888: Ст. Новаковић, Српска краљевска академија и неговање српског језика, Глас Српске краљевске академије X.

Новаковић 1894: Ст. Новаковић, Српска граматика, Београд: Државна штампарија.

\section{ЛИТЕРАТУРА}

Белић 1999: А. Белић, O великим ствараоиима, Сабрана дела 6, Београд: Завод за уџбенике.

ECH 2008: Енииклопедија српског народа, Београд: Завод за уџбенике.

Јовановић Симић 2017a: Јелена Јовановић Симић, О значењу и употреби временских глаголских облика у светлу учења београдске лингвистичке школе - презент, Научни састанак слависта у Вукове дане, 46/1, 125-137. 
Јовановић Симић 2017б: Јелена Јовановић Симић, О квалификативу и апсолутиву са лингвистичког и вербатолошког гледишта, Лик, 3/4, Андрићград, 93-112.

Јовановић Симић 2017в: Јелена Јовановић Симић, О употреби аориста и имперфекта у делима српских реалиста, у: Језик, књижевност, уметност, Милош Ковачевић (ред.), Крагујевац: Филолошкоуметнички факултет, 25-34.

Јовановић Симић 2018а: Јелена Јовановић Симић, Новија проучавања глаголских времена у српском језику (Ј. Вуковић, П. Сладојевић, К. Милошевић), Српски језик, XXIII, 219-235.

Јовановић Симић 2018б: Јелена Јовановић Симић, Учење А. Белића и београдске лингвистичке школе о значењу и употреби глаголских временских облика, Научни састанак слависта у Вукове дане, 47/3, 51-67.

Јовановић Симић 2018в: Јелена Јовановић Симић, О значењу и употреби врста перфеката, Наш језик, 49/1, 27-42.

Јовановић Симић 2019: Јелена Јовановић Симић, О значењу и употреби футура (првог и другог), Српски језик, XXIV, 295-313.

Симић 1991: Р. Симић, О намем књижевном језику, Никшић: Унирекс.

Симић 2009: Радоје Симић, Нормативни и употребни статус футуроида 'ћу/ћеш...+ да + презент', Научни састанак слависта у Вукове дане, 38/1, 51-55.

Симић/Јовановић 2007: Р. Симић и Ј. Јовановић, Српска граматика, Београд: Научно друштво за неговање и проучавање српског језика - Jaсен.

Симић/Јовановић Симић 2017: Радоје Симић, Јелена Јовановић Симић, О неким аспектима граматичког и физичког времена у структури српског језика, у: Путевима речи - Зборник радова у част Даринки Гортан Премк, ур. Рајна Драгићевић, Београд, 583-593.

Стевановић 1991: М. Стевановић, Савремени српскохрватски језик I-II, Београд: Научна књига. 


\section{NOTES ON SYNTHESIS IN NOVAKOVIC'S \\ SERBIAN GRAMATIC}

\section{Summary}

The author describes Novaković's contribution to Serbian grammar literature, and the science of language in general, which he invested in Serbian grammar (1894). The attention was dedicated to Novakovic's scientific views, his method of exposure, and terminological solutions, and a comparison was made with today's understanding of these issues, and today's grammar practice.

Keywords: grammar, syntax, sentence, case, time.

Jelena R. Jovanovic Simic 